\title{
Juridical Studies On Notary Deed Which Can Be Canceled And Void By The Law And Responsibilities Of Notary According To Law
}

\begin{abstract}
Arif Bahtiar Jefry ${ }^{1}$ and Lathifah Hanim ${ }^{2}$
Abstract. Notary deed can be canceled and void by law because of an error when a deed is contrary to the Act either intentionally or unintentionally by the parties who made it. Deed can be canceled, remain valid and binding as long as there has been no judicial decisions have permanent legal force canceling the deed. Unlike the deed can be canceled due to the manufacturing process does not satisfy the subjective element as set forth in Article 1320 paragraph (1) and (2) of the Civil Code. Deed null and void occurs due to the mechanism of making abuse substance UUJN Regarding the authority of notary in making authentic act and Article 1320 paragraph (3) and (4) of the Civil Code which is the objective conditions in performing an agreement, which is about a certain thing and the cause or causes of the allowed. In UUJN that as a notary in running his offense is proven, the notary must responsibility by way of sanction or sanctions, in the form of civil sanctions, administrative sanctions, criminal sanctions, the code of conduct or a combination of office notary witnesses. In Article 84 UUJN which reads: Actions violations committed by the notary of the provisions referred to in Article 16 paragraph (1) letter i, Article 16 paragraph (1) letter k, Article 41, Article 44, Article 48, Article 49, Article 50 Article 51 or Article 52 that resulted in a deed only has the strength of evidence as the deed under the hand or a certificate becomes null and void may be the reason for the injured party to demand reimbursement of losses, damages, and interest to the notary.

Keywords: Notary Deed, Canceled, Cancel By The Law, Responsibility, Notary.
\end{abstract}

\section{Introduction}

The existence of a Notary in Indonesia can not be separated from the Institute for Notary Law that govern them. The main role of the Notary in Indonesia is set by law is written by pouring the will of the client into an authentic deed, to the legal relations of the parties who requested his services, it can be said that the function provides legal services to the general public in the areas of civil law, which included in the field of public law. In performing their duties regulated by the Notary office Notary Act No. 30 of 2004 which was amended by Law office of Notary No. 2 of 2014, replacing the office of the Notary Regulation (PJN) which has been in force since 1860 (Staatsblad 1860 No.3), which is the forerunner of the Notary Law Institute in Indonesia. ${ }^{3}$

Notary as a public official authorized to make the authentic act can be held accountable for his actions in connection with his work in making the deed. The scope of responsibility includes the material truth above notary deed made. ${ }^{4}$

World notary is a blend of theory and practice at the level of the ideal between theory and practice in line or sometimes not mutually consistent meaning there is always a

\footnotetext{
${ }^{1}$ Master of Notaria law Students, Faculty of law, Universitas Islam Sultan Agung, email arifbahtiar27@gmail.com

${ }^{2}$ Faculty of Law Universitas Islam Sultan Agung

3 Henny Tanuwidjaja, 2012, Pranata Hukum Jaminan dan Sejarah Lembaga Hukum Notariat, Bandung, PT. Refika Aditama, p. 1.

${ }^{4}$ R.A. Emma Nurita, 2012, Cyber Notary Pemahaman Awal dalam Konsep Pemikiran, Bandung, PT. Refika Aditama, p. 2.
} 
theory support the practice, the world notary must be built not just taken and developed by or from the jurisprudence that has been there, but notaries also must be able to develop their own theories to support the implementation of the notary office tasks and experiences during stints notary office.

Article 38 (3) c UUJN confirmed that the contents of a deed is the will and desire of the parties applicant come before Notary. So that the contents of the deed is the applicant will or desire, not the desire or the will of the Notary, but Notary just framed it in the form of notarial deed in accordance UUJN. Therefore, if the contents of the deed in question by the parties or other interested parties, so that, with regard to the contents of the deed, is a problem of their own. For example, if the parties made a deed debts, which will be paid by the borrower in a period and a certain amount as stated in the deed. When a borrower defaults, and lend a difficult charge to the borrower. Which lend make a report on Complaints and Investigation Report to the police to follow up the report. To follow up on the complaint, because the loan agreements poured money in the form of notarial deed, to complete the Investigation Report before, the police will call a Notary Public in order to provide information relating to the deed of borrowing the money. In this regard needs to be questioned, whether wanprestasinya borrower for Notary deed? Or whether the borrower in a state unable to pay or when it does not have the money? In such events, the police should be noted, wanprestasinya borrower for or for what reasons? not only because of borrowing money is poured in immediately concluded Notary Notary deed must be called as a witness. Wanprestasinya that one of these parties, due to the reason of one of the parties themselves and not caused by the Notary deed, so that in this connection no reason or need to call the police to be placed as any Notary.

If the deed of Notary disputed by the parties or interested, then to finish should be based on nullification and cancellation Deed as a perfect evidence. ${ }^{5}$

Legal regulations relating to the legal consequences of an act that is in the making in violation of applicable regulations that result of regulation on notarial deed of cancellation may be filed. because it is an act that is flawed procedure, which is not competent to make the notary deed outwardly, formal and material, as well as the notarial deed is made not in accordance with the law on the notary deed. With some reason, as mentioned above, the legal consequences of the notarial deed becomes: Can be canceled (verniegbaar), Clear and void (nietigheid van rechtswege), Have the strength of evidence as under hand, Canceled by the parties themselves and canceled by a court decision that law has fixed for the application of the principle of presumption valid.

The position of the deed being processed in courts is still a deed valid and binding until the court decision that has binding. Thus, notarization remain valid and binding on the parties, or anyone with an interest in the deed.

The process of filing a lawsuit to declare a notary deed is not valid or there are defects in the mechanisms of the manufacturing procedure. then those who deny the validity of the notarial deed must be able to prove than 3 (three) aspects. namely the outer aspect. formal aspects and material aspects of the notarial deed. If it can be proven, then the notary deed becomes invalid certificate and with no consideration of the conditions are met the court may cancel aka. Furthermore, if the parties deny the

\footnotetext{
${ }^{5}$ Habib Adjie, 2011, Kebatalan dan Pembatalan Akta Notaris, Bandung, PT. Refika Aditama, p.
} 5. 
validity of the certificate can not prove a violation of the outward aspects, formal and material, it remains valid notary deed be perfect evidence. ${ }^{6}$

Throughout the year 2010 there were 12 cases have been dealt house certification Notary Supervisory Council, both central and local levels. Of these, four cases have been cut off, two of which were resolved peacefully, four other cases will not be processed because of expired and no appeal, and the remaining two is unclear because it is in the process of handling. The incident is one example of the case indicate that the notary profession is considered a certified home affairs become convoluted.

The case of a notary also occurred in Mojokerto. The notary allegedly embezzling funds from his clients so named as a suspect. It starts with land transactions in one of the residential complex in the district of Puri, Mojokerto. Although money has been deposited tens of millions of buyers as a sign, the deed of sale and purchase of land would not go out of the notary. Finally, the notary complainant alleged utilize incomprehension.

Naughty notary indeed exist. However, not a few notaries who were subjected to extortion. The last case override a number of notaries in Banjar, South Kalimantan. They suffer exploitation by unscrupulous local National Defense. Finally, in September 2010, the Head of BPN Banjar arrested by the Attorney General after getting complaints from the notary Banjar. He is suspected of extortion in the notarized deednotary who took care of the defense.

Of the few cases above, we can see the picture of the lives of the notary. It is inevitable that certain elements can do things that violate the code of conduct of his profession. ${ }^{7}$

Based on the description of the background of the authors are interested in researching and reviewing of the Notary Deed Which Can Be Canceled And Void By The Law And Responsibilities Of Notary According To Law, for the author will take the title of the research is: "Juridical Studies On Notary Deed Which Can Be Canceled And Void By The Law And Responsibilities Of Notary According To Law"

\section{Research methods}

In conducting this study, the authors use the research method used is research literature that is normative, that its source can be obtained from the study of literature and documents. This study aims to get secondary data, which among others is done by collecting and studying books, documents, official documents, the results are tangible results of research reports, and so on. ${ }^{8}$ But if researchers are still lacking, researchers can conduct an interview to the informant or informants to add information for this study. ${ }^{9}$

6 M. Luthfan Hadi Darus, 2017, Hukum Notariat dan Tanggungjawab Jabatan Notaris, (Yogyakarta, UII Press, p. 96.

${ }^{7}$ Hartanti Sulihandari, Nisya Rifiani, 2013, Prinsip-prinsip Dasar Profesi Notaris, Jakarta Timur, Dunia Cerdas, p. 2.

8 Soejono Soekamto, 1996, Pengantar Penelitian Hukum, Jakarta, UI Press, p. 12.

${ }^{9}$ Sri Mamuji et, al. , 2005, Metode Penelitian dan Penulisan Hukum, cet. 1, (Jakarta, Badan Penerbit Fakultas Hukum Universitas Indonesia, p. 22. 


\section{Results And Discussion}

\subsection{Context Notary Deed That Can Be Canceled and Void By the Law}

Context Notary Deed That Can Be Canceled and Void By the Law because of an error when a deed is contrary to the Act either intentionally or unintentionally by the parties who made it. Disability can lead to nullification notarial deed to a notary and in terms of sanctions or legal consequences of nullification be able Canceled and Cancel By the Law. Effects of nullification deed resulted in the legal act to be invalid or the legal act has no legal consequences.

\section{- Notary Deed Can be Canceled}

Can be Canceled is a sanction against a legal act is flawed juridical (cause nullification) in the form of cancellation of legal acts on the wishes of certain parties and the legal consequences of the cancellation was that a legal act is not a legal effect since the cancellation, and the cancellation or ratification of a legal act depends on certain parties, which led to The legal actions can be canceled or validated. Deed which sanctions may be canceled, remain valid and binding as long as there has been no judicial decisions have permanent legal force canceling the deed. Legal actions were covered by notarial deed can be canceled, if flawed judicial due to several reasons: incompetence, According to Article 1330 of the Civil Code was "incompetent to make approval of the people who have not grown up ...". 1945 Constitution as the constitutional basis, has set the age limit criteria of maturity or skills to act in deed, as outlined in article 39 paragraph 1 of Notary Law that is at least 18 years old and has been married and legally competent. And defects of the will, the word agree an absolute essentialia or elements that exist for the formation of an agreement and a subjective requirement for a legal contract as defined in Article 1320 of the Civil Code. Unauthorized agreement becomes flawed if the will as defined in article 1321 of the Civil Code, namely: The mistake of the presence / Heresy (Dwaling), presence of Fain (Dwang) and the existence of Fraud (Bedrog).

One of examples of this research study is the decision of the Court in Case Number: 1 / PDT / G / 2015 / PN.Bkt.

Based on what is described in the Case, that the complaint filed by the Plaintiff to the Defendant came from the issuance of the Certificate Properties No. 1417, No. 1418 Certificate of Property Rights and Property Rights Certificate No. 1419, the third certificate is written on behalf of 1 . Djamaris, 2. Djusmiati, 3 . Syamsir, 4. Wahyu Suci Rahmawati, 5. Yusra and 6. Nurni Arifah made by Defendant I with full engineering and fabrication Letters. The third certificate is the result of the breakdown of Property Rights Certificate Number 219 Measure Letter No. 48/1979 on behalf of Defendant Lamsinar by I. And this is the Torts.

Separation of Certificate Properties Number 219 into 3 parts, namely Certificate Properties Number 1417, Certificate of Property Rights No. 1418, and the Certificate of Property Rights Number 1419 and excluded the Plaintiff 2 Fitriati as Heir and Nurhayati (Alm) This has eliminated the rights of Fitriati and Defendant I million have included also has included Wahyu Suci Rahmawati, whereas Wahyu Suci Rahmawati is the biological child of Defendant I alive and this is Torts.

SHM No. 1417, SHM No. 1418, and SHM No. 1419 on behalf of 1 . Djamaris, 2. Djusmiati, 3. Syamsir, 4. Wahyu Suci Rahmawati, 5. Yusra, 6. Numi Arifah is flawed and void because the Defendant I unbeknownst Plaintiff Penguggat I and II with full 
engineering and forgery of letters has divided SHM No. Measure Letter No. 219 48/1979 into three (3) parts SHM No. 1417, SHM No. 1418, and SHM No. The 1419. With the evidence of the plaintiff, such as not entering a name Fitriati (Plaintiff II) as heirs of Nurhayati (Alm) and this has eliminated the right of Plaintiff II and the Defendant I also have to enter a name Wahyu Suci Rahmawati (Defendant V) while Defendant $\mathrm{V}$ is the biological child of the first defendant who is still alive and this is an Torts; with other evidence such as copy of the heirs, etc.

Supposedly in breaking Certificates that must be known about the transition of land rights. Transition Land Rights must be accompanied by a letter of proof as the heirs and the division of inheritance deed. It is governed by Article 42 paragraph (4) PP 24 of 1997 on Land Registration (PP Land Registration) which reads, "If beneficiaries more than one person and the switchover time such rights are registered with the deed of division of inheritance, which contains information that rights to land or property rights to the apartment units specified falls to a certain beneficiaries, registration of land rights or the transfer of ownership of the apartment units were made to the beneficiaries concerned by virtue of proof as the heirs and the division of inheritance deed. "

If not as described in Article 42 paragraph (4) PP 24 of 1997 on registration of land was then said to Torts and the certificate can be canceled, as in this case, as the Defendant does not include the first Heir and include one person hostage in order not to break heritage Property Rights Certificate Number 219 Measure Letter No. $48 / 1979$.

See Entitlement Joint Deed made by notary Djanur Manalu, SH (Defendant VIII) to SHM 1418 and SHM 1419; by not entering the name Fitriati (Plaintiff II) as heirs of Nurhayati (Alm) and this has eliminated the right of Plaintiff II and the Defendant I also have to enter a name Wahyu Suci Rahmawati (Defendant V) while Defendant V is the biological child of the Defendant I were still alive is not correct and legally flawed.

APHB legal basis is Article 111 Paragraph 3, Clause 4 and Clause 5 PMA / KBPN (Minister of State for Agrarian Affairs / Head of National Defense) No. 3 of 1997. For each of this verse says:

(3) Acts regarding the division of inheritance as referred to in paragraph (2) may be made in the form of a deed under the hand by all the heirs, witnessed by two witnesses or a notary deed.

(4) If the heirs of more than 1 (one) and there is no inheritance, then the registration is done right transition to the heirs as joint ownership and the distribution of rights can then be carried out in accordance with Article 51 of Government Regulation No. 24 of 1997.

(5) If the heirs of more than 1 (one) and at the time of registration of transfer of rights accompanied by the deed of division of inheritance, which contains information that the rights to the land or the Right of Ownership on Unit Flats are certain fall to 1 (one) of the beneficiaries, the recording done right transition to the recipient heritage concerned by the division of inheritance deed.

While Article 51 of Government Regulation No. 24 of 1997 reads: (1) The division of collective rights to land or property rights to the apartment units are entitled each holder of common rights listed by deed made PPAT authorized under applicable law 
to prove an agreement between the rights holders together about the joint distribution of rights.

According to Article 111 Paragraph 4 PMA / KBPN No. 3 of 1997, the manufacture of APHB made by PPAT happen if in future the distribution of rights.

Through this article, also means that in the event of death due Heir law as holders of Rights to Land, the Land Rights namechanged certificate on behalf of the beneficiary (eg on the basis of a Certificate of Heir).

Once a certificate of Land Rights is written the name of the beneficiary, later APHB will be made in case of distribution of rights. The division of these rights can be passed on the basis of a written provision in Article 51 of Government Regulation No. 24 of 1997 which speaks of APHB.

So it is said that the Entitlement Joint Deed made by notary Djanur Manalu, SH (Defendant VIII) to SHM 1418 and SHM 1419; Violating Terms of Legitimacy An Engagement namely the required agreement of the parties, then to not include names Fitriati (Plaintiff II) as heirs of Nurhayati (Alm).

Explained Article 1320 of the Civil Code is set on the terms of validity of an engagement which terms Subjective (1. The agreement of the parties and the parties 2. Skills), whereas the objective requirement is (3. One particular thing, and 4. Because kosher).

And the validity of the terms of the agreement included in the notarized deed, which is listed in the initial terms of subjective and objective requirements listed deed preformance deed bodies as the contents of the deed.

Then the legal consequences non-fulfillment of the requirements mentioned above, the Subjective Entitlement Joint Deed made by notary Djanur Manalu, SH (Defendant VIII) can be canceled.

And related terms are lawful reasons, the process of making Entitlement Commons Deed of Notary Djanur Manalu, SH (Defendant VIII) to SHM 1418 and SHM 1419. SHM 1418 and SHM 1419because it is a legal act, the certificate is legally flawed.

Then the legal consequences of non-fulfillment of the requirements mentioned above, the objective Entitlement Joint Deed made by notary Djanur Manalu, SH (Defendant VIII) becomes null and void.

Seeing the sale and purchase deed made by Notary Elfita Achtar, SH (Defendant IX) between the Defendant I, Defendant and Defendant II VI Defendant VII; with the object SHM 1418 and SHM 1419 with no lawful reason then make the deed of sale is illegal and null and void.

Then the legal consequences of non-fulfillment of the requirements mentioned above, the objective deed of sale and purchase made by Notary Elfita Achtar, SH (Defendant IX) between the Defendant I, Defendant and Defendant II VI Defendant VII; become null and void.

- Cancelation of Notarial Deed By The Law

Void is a civil sanction against a legal act is flawed juridical (cause nullification), in the form of legal acts which do not have legal consequences since the act of the law or powerless retroactively (ex tunc) or legal actions that are not applicable since the deed is signed and legal actions referred to in the certificate is considered never happened. In case null and void, then among the parties there is no right to sue each other court upfront, therefore engagement from the beginning has failed or does not happen all the time. Legal actions covered by notarial deed can be clear 
sake of the Law, if juridic flawed.

Unlike the deed can be canceled due to the manufacturing process does not satisfy the subjective element as set forth in Article 1320, paragraph 1 and 2 of the Civil Code. Deed null and void occurs because the mechanisms of substance abuse UUJN Regarding making the notary authority in making authentic act and Article 1320, paragraph 3 and 4 of the Civil Code which is an objective requirement in the conduct of an agreement, which is about a certain thing and the cause or causes are allowed.

The notarial deed that void is influenced by several factors, this is because the deed made by breaking and non-fulfillment:

- Authentic act outwardly element (Uitwendige Bewijskracht).

- Formal elements of an authentic deed (Formale Bewijskracht).

- Material element (Materiele Bewijskracht).

- Elements of the Civil Code Article 1320, paragraph 3 on a particular issue (Een onderwerp).

- Elements of paragraph 4 of Article 1320 of the Civil Code of the causes of the exposure (Een geoorlofde oorzaak).

Noting violations in the mechanism of a deed authenticated by the notary, about the non-fulfillment of the elements outward, formal, material and infringement of Article 1320, paragraph 3 of the Civil Code must have been very clear that the implementation of the rights and obligations under the deed should not be implemented, because contrary to the law, with thus, the deed as it should be prevented implementation.

Terms of subjective and objective as defined in Article 1320 of the Civil Code which will be poured into the authentic act, namely the required subjective listed in the beginning of the deed or the head of the deed and objective conditions included in the body of the deed as the contents of the deed and the realization of Article 1338 KHHPerdata which reflects the principle of freedom of contract which will provide certainty and legal protection of the parties regarding the contract they made in accordance with Article 1337 of the Civil Code.

Furthermore, if the contents of the notarial deed is not eligible objective, then the deed null and void and the legal consequences of the deed that has never been considered (inexistence), thus since then the authentic act signed and legal actions are in deed deemed never happened. ${ }^{10}$

One example source of this research study is the Court's decision in case No. 08 / Pdt.G / 2016 / PN.Spt.

The plaintiff further that the overall reasons contained in the Court's decision No. 08 / Pdt.G / 2016 / PN.Spt. is as follows:

See Deed of Joni, SH., MH., Number 20 dated October 28, 2008 on the "in and out as state-owned as well as budget changes the company's CV. PUTRA JAYA" expressed as applicant is DEFENDANT I were acting for itself and as the attorney spoken of PLAINTIFF, Asharuddin Marbun and (late) Marulam Marbun.

In deed DEFENDANT 'mention of the power of word of mouth, but in fact the Plaintiff never even authorize either in writing or orally, it is worth and should DEFENDANT II check directly with the authorizing of the truth of the verbal authorization in order to avoid problems.

10 M. Luthfan Hadi Darus, 2017, Hukum Notariat dan Tanggungjawab Jabatan Notaris, Yogyakarta, UII Press, p. 104. 
Described the sense the power under Article 1792 of the Civil Code, namely: "The authorization is an agreement which contains the granting of power to others who receive it to implement something on behalf of someone who gives power." Thus, there must be two parties, namely the authorizing and power.

The Notary deed is legally flawed because PLAINTIFF never even authorize, in writing especially verbally, to take legal actions as stated in the deed DEFENDANT II.

With evidence of the plaintiff, that the plaintiff had never authorized the Defendant was enough to prove any statement and / or agreements on behalf PLAINTIFF is not properly and legally flawed.

So it is said that the Deed Joni, SH., MH., Number 20 dated October 28, 2008 Violating Terms of Legitimacy An Engagement namely the required agreement of the parties, with no power PLAINTIFF give DEFENDANT I have been able to prove there was no agreement that the plaintiff gave in deed DEFENDANT II.

And also Violating Terms of Legitimacy An Engagement namely the required skills of the parties, then I can be qualified DEFENDANT incompetent act (defects in the will) for and on behalf of the deed DEFENDANT II is since no power is given by the PLAINTIFF.

Explained Article 1320 of the Civil Code is set on the terms of validity of an engagement which terms Subjective (1. The agreement of the parties and the parties 2. Skills), whereas the objective requirement is (3. One particular thing, and 4. Because kosher).

And the validity of the terms of the agreement included in the notarized deed, which is listed in the initial terms of subjective and objective requirements listed deed preformance deed bodies as the contents of the deed.

Then the legal consequences non-fulfillment of the requirements mentioned above, the Subjective DEFENDANT II deed number 20 dated October 28, 2008 be canceled.

And related terms because kosher, then the action DEFENDANT I stating as the attorney orally from PLAINTIFF (quad non) and action DEFENDANT II who did not ask directly to PLAINTIFF truth about the power of word of mouth, then simply turned out that something is not allowed (not kosher) according to the law, custom and decency regulations.

Then the legal consequences of non-fulfillment of the requirements mentioned above, the objective DEFENDANT II deed number 20 dated October 28, 2008 to be null and void.

\subsection{Responsibilities Of Notary Deed Which Can Canceled and Void By the Law}

Based UUJN set that as a notary in running his offense is proven, the notary must responsibility by way of sanction or sanctions, in the form of civil sanctions, administrative sanctions, criminal sanctions, the code of conduct or a combination of office notary witnesses. The sanctions are already regulated in such a way, previously set in Regulation Notary (PJN) and now UUJN and ethical codes notary office. In practice it is found the fact that a legal action or offenses committed by a notary public can actually administrative or civil sanctions or codes of conduct of office, but later withdrawn or qualified as a criminal offense committed by a notary.

Thus, a notary public office should be responsible for the deed he has done, whether it be administrative liability, civil liability if it is proved in deed there are criminal acts that 
violated.

Tort committed by a notary are as contained in Decision No. 1 / PDT / G / 2015 / PN.Bkt, in this case is a notary Notaries lawsuit Djanur Manalu, SH as (Defendant VIII). Such decisions are essentially act Defendant VIII mentions an unlawful act and declare null and void the Deed of Distribution of Wealth Together SHM No. 1419 to on behalf of Defendant I (Syamsir).

Likewise void Deed of Distribution Assets Together SHM No. 1418 to on behalf of Defendant II (Djamaris) conducted by Notary Djanur Manalu, SH (Defendant VIII)

The cancellation of the deed is because the deed in question contains the elements of a mistake, straying or oversight (dwaling), because it had to be canceled. Besides evidence of falsification of documents and in making the Deed of Distribution of Assets Along with entering the name Fitriati (Plaintiff II) as heirs of Nurhayati (Alm) and this has eliminated the right of Plaintiff II and the Defendant I also have to enter a name Wahyu Suci Rahmawati (Defendant V) Defendant whereas V is the biological child of the Defendant I were still alive, and this is an Torts;

Based on the errors of the creator, when both illegal as the cause, arising from the loss was already present, and then we step on the manufacturer's liability case. This is because there is no legal violation in the absence of these actions related to the subject, until the error element of the maker of misconduct. An error can be either intentional or negligence.

Tort in Article 1365 of the Civil Code provides an explanation perpetrators should not be active in doing so, it also includes a passive act of the person can also be said of a tort. That with passivity or inaction of the person, whereasthe person is conscious and able to suspect and to prevent an unlawful act, it is thus the person will also commit an unlawful act.

For example, the parties are facing a notary to make the evidence, but no particulars are not correctly described by the parties (for example there is one applicant not competent to act) and acknowledged by a notary or reasonably suspected by a notary public such information not true, but the notary did not provide feedback or insight to the parties. With the notary's silence, causing problems in the future, it can be said noraris committed an unlawful act passively.

Notaries in running the office can make mistakes in the process of making an authentic deed, as a result of that error noraris should be responsible in this case as civil responsibility if the parties harmed by the notary deed.

Tort committed by a notary are as contained in Decision No. 08 / Pdt.G / 2016 / PN.Spt, in this case is a notary Notaries lawsuit Joni, SH., MH., As (the second defendant), Such decision in principle to mention acts of Defendant II is an unlawful act and declare null and void Deed Joni, SH., MH., Number 20 dated October 28, 2008 on the "in and out as state-owned as well as budget changes the company's CV. PUTRA JAYA" made before the second defendant with all legal consequences arising and sourced from the deed deed.

The cancellation of the deed is because the deed in question contains the elements of a mistake, straying or oversight (dwaling), because it had to be canceled. Besides evidence of fraud in making Deed Joni, SH., MH., Number 20 dated October 28, 2008 on the "in and out as state-owned as well as budget changes the company's CV. PUTRA JAYA" by applicant ie DEFENDANT I were acting for itself and as the power of word of mouth from PLAINTIFF, Asharuddin Marbun and (late) Marulam Marbun, in 
fact, that PLAINTIFF never even authorize, in writing especially verbally, to take legal actions as stated in the deed DEFENDANT II and Defendant II did not ask directly to the authorizing the truth about oral authorization.

If there are parties or applicant judge or assume or determine that notarial deed of violating the provisions of Article 84 UUJN, then the party providing such assessments should be able to prove through the court process (lawsuit) and ask for reimbursement, compensation and interest to be can prove his judgment, pointing out provisions laid or which articles are violated by a Notary, and on this lawsuit, a notary shall provide resistance or explanation. If plaintiff can prove his claim, and the court ruled the deed in question did not have the strength of evidence as the deed under hand or canceled by law, and the judge imposes a compensation to the Notary to pay to the plaintiff, in this suit all levels of the judiciary can be reached by a Notary, until there is a decision that has the force of law is certain.

If the court decides that the deed has the strength of evidence as the deed under hand or null and void, then the court's decision can be prosecuted of Notary fees, damages and interest. Similarly, if it turns out a lawsuit is not proven or rejected, then it is possible Notary concerned to file a lawsuit to them or Parties that have sued. case This is an effort to maintain the rights and obligations of Notaries in performing his respective duties, relating to the deed made before or by the Notary. ${ }^{11}$

UUJN set firmly in a civil notary responsibilities as has been regulated in Article 84 UUJN which reads: Violations committed by the notary of the provisions referred to in Article 16 paragraph (1) letter i, Article 16 paragraph (1) letter $k$, Article 41, Article 44, Article 48, Article 49, Article 50, Article 51, or Article 52 which resulted in a deed only has the strength of evidence as the deed under the hand or a certificate becomes null and void may be the reason for the injured party to demand reimbursement of losses, damages, and interest to the notary.

Civil liability as contained in Article 34 UUJN, had previously been set out in Article 60 PJN. The conditions that must be met to hold a civil notary to replace losses, and interest costs incurred due to errors in the manufacture of authentic deed notary are:

- Regarding matters expressly determined by PJN.

- If a deed because it does not meet the requirements regarding the form, canceled in court or simply act as a deed made under the hand.

- In the case where, according to the provisions of Article 1365, 1366, and 1367 Civil Code there is an obligation to pay damages.

Due to the decline or reduced levels authentic deed proving become deed under the hand, causing losses suffered by the plaintiff and the plaintiff can prove with certainty and real numbers. By this the plaintiff can ask a notary to be liable to pay damages to the notary, as contained in Article 84 UUJN which states: Proof as a deed under hand or a certificate becomes null and void may be the reason for the party suffering a loss to demanding reinbursement costs, damages, and interest to the notary.

The legal consequences for notaries who do not want to run the civil responsibility to indemnify, interest and costs incurred after the court decisions that have permanent legal force, the notary can be declared bankrupt.

And on that basis, the notary may be removed temporarily, as contained in Article 9 of Act No. 30 of 2004 concerning Position Noraris as amended by Act No. 2 of 2014 which

\footnotetext{
${ }^{11}$ Habib Adjie, 2018, Hukum Notaris Indonesia Tafsir Tematik Terhadap UUJN 2004, Bandung, PT Refika Aditama, p. 225.
} 
reads: Notary suspended from office for:

- In the process of bankruptcy or postponement of debt payment obligations.

- Being under guardianship.

- Misconduct.

- Violation of obligations and prohibitions office.

- Is undergoing a period of detention.

\section{Closing}

\subsection{Conclusion}

Based on this research can be concluded as follows:

- Context Deed That Can Be Canceled and Void By the Law

So Context Deed to Canceled and Void by the law because of an error when a deed is contrary to the Act either intentionally or unintentionally by the parties who made it. The Notary Deed can Canceled remain valid and binding as long as there has been no judicial decisions have permanent legal force canceling the deed. Legal actions were covered by notarial deed can be canceled, if flawed juridical caused by several things: incompetence in acting and disabled will or not agree on making it. While the Deed Cancel By the law has no legal effect since the onset of the legal act or power downs or the legal act to be invalid since the deed was signed and legal actions referred to in the certificate is considered never happened. In case null and void, then among the parties there is no right to sue each other court upfront, therefore engagement from the beginning has failed or does not happen all the time.

- Responsibilities Of Notary Deed that Can be Canceled and Void By the Law

Arranged in UUJN that as a notary in running his offense is proven, the notary must responsibility by way of sanction or sanctions, in the form of civil sanctions, administrative sanctions, criminal sanctions, the code of conduct or a combination of office notary witnesses. The sanctions are already regulated in such a way, previously set in Regulation Notary (PJN) and now UUJN and ethical codes notary office. In practice it is found the fact that a legal action or offenses committed by a notary public can actually administrative or civil sanctions or codes of conduct of office, but later withdrawn or qualified as a criminal offense committed by a notary. UUJN set firmly in a civil notary responsibilities as has been regulated in Article 84 UUJN which reads: Violations committed by the notary of the provisions referred to in Article 16 paragraph (1) letter i, Article 16 paragraph (1) letter $k$, Article 41, Article 44, Article 48, Article 49, Article 50, Article 51, or Article 52 which resulted in a deed only has the strength of evidence as the deed under the hand or a certificate becomes null and void may be the reason for the injured party to demand reimbursement of losses, damages, and interest to the notary. And in Article 84 UUJN which states: Proof as a deed under hand or a certificate becomes null and void may be the reason for the party suffering a loss to demanding reinbursement costs, damages, and interest to the notary.

The legal consequences for notaries who do not want to run the civil responsibility to indemnify, interest and costs incurred after the court decisions that have permanent legal force, the notary can be declared bankrupt. 


\section{Bibliography}

\section{Books}

[1] Habib Adjie, 2018, Hukum Notaris Indonesia Tafsir Tematik Terhadap UU No. 30 Tahun 2004 Tentang Jabatan Notaris, Bandung: PT. Refika Aditama.

[2] Habib Adjie, 2011, Kebatalan dan Pembatalan Akta Notaris, Bandung, PT. Refika Aditama.

[3] Hadi Darus, M. Luthfan, 2017, Hukum Notariat dan Tanggungjawab Jabatan Notaris, Yogyakarta, UII Press.

[4] Hartanti Sulihandari, 2013, Nisya Rifiani, Prinsip-prinsip Dasar Profesi Notaris, Jakarta Timur, Dunia Cerdas.

[5] Nurita, R.A. Emma, 2012, Cyber Notary Pemahaman Awal dalam Konsep Pemikiran, Bandung, PT. Refika Aditama.

[6] Soejono Soekamto, 1986, Pengantar Penelitian Hukum, Jakarta, UI Press,

[7] Sri Mamuji et, al., 2005, Metode Penelitian dan Penulisan Hukum, cet. 1, Jakarta, Badan Penerbit Fakultas Hukum Universitas Indonesia.

[8] Henny Tanuwidjaja, 2012, Pranata Hukum Jaminan dan Sejarah Lembaga Hukum Notariat, Bandung, PT. Refika Aditama.

\section{Legislation}

[1] Constitution of the Republic of Indonesia of 1945

[2] Civil Code / BW (Burgerlijke wetboek)

[3] Act No. 22014 on Notary 